\title{
Profil Karsinoma Kolorektal di Laboratorium Patologi Anatomi Fakultas Kedokteran Universitas Andalas Priode Januari 2009 sampai Desember 2011
}

\author{
Muflikal Hamdi ${ }^{1}$, Asril Zahari $^{2}$, Aswiyanti $^{3}$
}

\begin{abstract}
Abstrak
Pada stadium awal carcinoma colorectal tidak menunjukan gejala klinis yang khas, sehingga sebagian besar penderita datang pada stadium lanjut. Tujuan penelitian ini adalah untuk melihat profil carcinoma colorectal di laboratorium Patologi Anatomi Fakultas Kedokteran Universitas Andalas. Penelitian ini dilakukan pada periode Januari 2009 sampai Desember 2011 dengan metode deskriptif retrospektif. Data penelitian diambil dari rekam medis penderita carcinoma colorectal dalam penelitian yang telah dilakukan pada bulan Juni 2012 sampai bulan Oktober 2012. Pada penelitian ini di temukan 260 kasus carcinoma colorectal dengan histopatologi terbanyak yaitu adenokarsinoma 217 kasus (83,47\%) dan grading/diferensiasi II sebanyak 93 kasus (42,85\%). Insiden carcinoma colorectal ditemukan pada perempuan lebih tinggi daripada laki-laki dengan perbandingan $1,18: 1$. Kelompok umur terbanyak adalah 51-60 tahun (28,08\%) dengan usia termuda 16 tahun dan tertua 86 tahun. Lokasi carcinoma colorectal tersering ditemukan di rektum 131 kasus (50,39\%) disusul rektosigmoid 37 kasus (14,23\%) dan sigmoid 27 kasus $(10,39 \%)$ dengan gejala klinis terbanyak BAB berdarah dan berlendir. Pada saat skrining dengan melakukan rektal toucher masa carcinoma colorectal akan dapat teraba, sehingga kasus ini dapat ditemukan pada stadium dini dan angka morbiditas dan mortalitas akibat penyakit ini dapat diturunkan.
\end{abstract}

Kata kunci: profil, carcinoma colorectal, patologi anatomi

\section{Abstract}

In the early stages of colorectal carcinoma does not show typical clinical symptoms, so most people come at an advanced stage. The objective of this study was to determine the profile of colorectal carcinoma in the anatomic pathology laboratory Andalas University Faculty of Medicine. The research was conducted during the period January 2009 until December 2011 with retrospective descriptive method and the data were taken from the medical records of patients with colorectal carcinoma in the research that has been conducted in June 2012 until October of 2012. Found in this study in 260 cases of colorectal carcinoma with the highest histopathology adenocarcinoma 217 cases (83.47\%) and grading/differentiation II as many as 93 cases (42.85\%). Colorectal carcinoma incidence found in women is higher than men with a ratio of 1.18: 1. Largest age group was 51-60 years (28.08\%) with the youngest aged 16 and the oldest 86 years. Most common location of colorectal carcinoma was found in the rectum 131 cases (50.39\%) followed rektosigmoid 37 cases (14.23\%) and sigmoid 27 cases (10.39\%) with clinical symptoms defecate most bloody and slimy. The screening by rectal toucher will be seen colorectal carcinoma clearly, so this case can be found at an early stage and morbidity and mortality from this disease can be reduced.

Keywords: profile,colorectal carcinoma, anatomic pathology

Affiliasi penulis : 1. Pendidikan Dokter FK UNAND (Fakultas Kedokteran Universitas Andalas Padang), 2. Bagian IImu Bedah FK UNAND/RS Dr. M. Djamil Padang, 3. Bagian Patologi Anatomi FK UNAND
Korespondensi : Muflikal Hamdi, E-mail: muflikalhamdii@gmail.com, Telp: 085274722631 


\section{PENDAHULUAN}

Perubahan pola hidup masyarakat menyebabkan pola penyakit pun mengalami perubahan. Masalah kesehatan utama masyarakat telah bergeser dari penyakit infeksi ke penyakit degeneratif dan keganasan. Insiden penyakit keganasan, khususnya penyakit carcinoma colorectal cenderung meningkat setiap tahunnya. Carcinoma colorectal menempati urutan ketiga setelah kanker paru dan kanker prostat pada laki-laki dan kanker payudara pada perempuan, sebagai penyebab kematian akibat kanker di Amerika Serikat. Pada tahun 2012 carcinoma colorectal ditemukan 143.460 kasus baru dengan angka kematian akibat kanker mendekati angka 55.000 kasus. ${ }^{1}$

Insiden carcinoma colorectal mengalami peningkatan di Indonesia. Berdasarkan data pusat Patologi Anatomi dilaporkan bahwa carcinoma colorectal termasuk dalam 10 karsinoma terbanyak di Indonesia, dengan frekuensi 8,16\% tahun 1999 diantara seluruh penyakit keganasan. Di FKUI pada tahun 1998 menempati urutan ke-4 (4,6\%) dari semua keganasan dan urutan ke-3 (6\%) dari registrasi RSCM Jakarta. Di Patologi Anatomi FKUA pada tahun 1999 dilaporkan carcinoma colorectal menempati urutan ke $2(11,13 \%)$ dari 10 karsinoma terbanyak setelah karsinoma payudara.

Insiden carcinoma colorectal mulai meningkat secara bermakna setelah usia 40 tahun. Insiden yang muncul sebelum usia 40 tahun biasanya terjadi bersamaan dengan faktor risiko lain, terutama faktor familial. Faktor familial akan meningkatkan risiko seseorang untuk menderita carcinoma colorectal 3 kali lebih besar dari pada orang normal. Insiden carcinoma colorectal pria dan wanita hampir sama, dengan rasio $1: 1^{1-2}$

Penyebab pasti dari carcinoma colorectal belum diketahui, namun ada beberapa faktor risiko yang dapat meningkatkan terjadinya penyakit ini, antara lain; faktor lingkungan, faktor genetik, riwayat karsinoma dalam keluarga dan kondisi medis lain seperti kolitis ulseratif (radang kolon) dan penyakit Crohn's. ${ }^{3-5}$

Gejala yang timbul pada pasien carcinoma colorectal tidak spesifik dan timbul secara perlahanlahan, sehingga tidak disadari oleh pasien, seperti:
Buang Air Besar (BAB) berdarah dan berlendir, susah $\mathrm{BAB}$, nyeri perut, lemah lesu dan penurunan berat badan. $^{6}$ Secara histopatologi, sebagian besar penderita carcinoma colorectal merupakan tipe histopatologi adenokarsinoma dengan berbagai tingkat grading/diferensiasinya. ${ }^{7}$

Kebanyakan dari penderita carcinoma colorectal yang dideteksi dengan program penapisan dapat dipulihkan, namun sebagian pasien besar kasus datang dalam stadium lanjut. Dengan melakukan pemeriksaan colok dubur $10-20 \%$ carcinoma colorectal dapat dideteksi, karena lebih dari $60 \%$ carcinoma colorectal berada di rektum dan sigmoid. Jika kita dapat meyakinkan masyarakat untuk melakukan penapisan regular seperti, pemeriksaan colok dubur, fecal occult blood test (FOBT), sigmoidoskopi, maka ini dapat menurunkan angka morbiditas dan mortalitas akibat penyakit ini. ${ }^{1}$

Penelitian ini bertujuan untuk mengetahui profil carcinoma colorectal di laboratorium patologi anatomi Fakultas Kedokteran Universitas Andalas Padang.

\section{METODE}

Jenis penelitian ini adalah penelitian deskriptif retrospektif. Penelitian ini dilakukan di Laboratorium Patologi Anatomi Fakultas Kedokteran Universitas Andalas Padang periode Januari 2009 sampai Desember 2011. Populasi penelitian ini adalah semua catatan medik penderita carcinoma colorectal yang di periksa di Laboratorium Patologi Anatomi Fakultas Kedokteran Universitas Andalas Padang Periode Januari 2009 sampai Desember 2011.

Teknik pengambilan sampel menggunakan teknik total sampling dengan mengambil seluruh sampel yang memenuhi kriteria inklusi dan eksklusi mulai dari Januari 2009 sampai Desember 2011. Analisis data menggunakan analisis univariat untuk mengetahui profil carcinoma colorectal yang di periksa di Laboratorium Patologi Anatomi yang akan ditampilkan dalam bentuk grafik, tabel, dan diagram.

\section{HASIL}

Berdasarkan penelitian yang telah dilakukan tentang gambaran carcinoma colorectal umur di laboratorium Patologi Anatomi Fakultas Kedokteran Universitas Andalas Padang periode Januari 2009 
sampai Desember 2011 didapatkan kasus carcinoma colorectal 260 kasus, dengan perbandingan laki : perempuan $1: 1,18$.

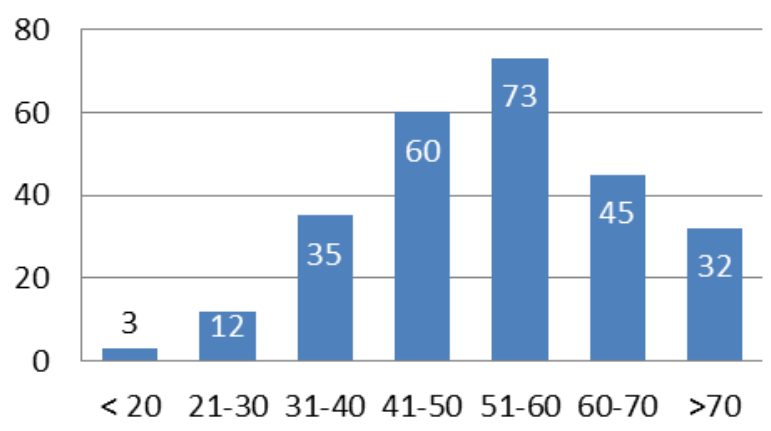

Gambar 1. Distribusi profil carcinoma colorectal menurut umur

Gambar 1 memperlihatkan kasus carcinoma colorectal pada tahun 2009 sampai 2011 secara keseluruhan mulai meningkat pada kelompok umur $31-40$ tahun sebanyak 35 kasus (23,08\%) dan terbanyak pada kelompok umur 51-60 tahun 73 kasus (28,08\%). Terendah ditemukan pada kelompok usia < 20 tahun 3 kasus $(1,15 \%)$.

Tabel 1. Distribusi profil carcinoma colorectal menurut lokasi

\begin{tabular}{lcc}
\hline Lokasi & $\begin{array}{c}\text { Jumlah } \\
\text { kasus }\end{array}$ & $\begin{array}{c}\text { Persentase } \\
\text { (\%) }\end{array}$ \\
\hline Sekum & 2 & 0,77 \\
Kolon asendens & 8 & 3,07 \\
Kolon transversum & 4 & 1,53 \\
Kolon desendens & 19 & 7,31 \\
Sigmoid & 27 & 10,39 \\
Rektosigmoid & 37 & 14,23 \\
Rektum & 131 & 50,39 \\
Anorektal & 26 & 10,00 \\
Tidak Tercantum & 6 & 2,31 \\
\hline \multicolumn{1}{c}{ Jumlah } & 260 & 100 \\
\hline
\end{tabular}

Pada Tabel 1 terlihat bahwa lokasi carcinoma colorectal terbanyak adalah di rektum yaitu 131 kasus $(50,39 \%)$ dan lokasi terendah ditemukan di sekum sebanyak 2 kasus $(0,77 \%)$ namun, terdapat 6 kasus $(2,31 \%)$ tidak tercantum lokasi carcinoma colorectal
Tabel 2. Distribusi profil carcinoma colorectal menurut jenis histopatologi

\begin{tabular}{|c|c|c|}
\hline Jenis Histopatologi & $\begin{array}{l}\text { Jumlah } \\
\text { kasus }\end{array}$ & $\begin{array}{c}\text { Persentase } \\
\text { (\%) }\end{array}$ \\
\hline Adenokarsinoma & 217 & 83,46 \\
\hline $\begin{array}{l}\text { Adenokarsinoma } \\
\text { musinosa }\end{array}$ & 31 & 11,92 \\
\hline Karsinoma sel signet ring & 4 & 1,54 \\
\hline $\begin{array}{l}\text { Karsinoma tidak } \\
\text { berdiferensiasi }\end{array}$ & 2 & 0,77 \\
\hline $\begin{array}{l}\text { Karsinoma } \\
\text { adenoskuamosa }\end{array}$ & 1 & 0,39 \\
\hline Karsinoma sel skuamosa & - & 0 \\
\hline Karsinoma sel kacil & - & 0 \\
\hline Karsinoma medular & - & 0 \\
\hline Metastasis & 5 & 1,92 \\
\hline Jumlah & 260 & 100 \\
\hline
\end{tabular}

Tabel 2 memperlihatkan jenis histopatologi paling banyak ditemukan adalah adenokarsinoma sebanyak 217 kasus (83,46\%) dan histopatologi Adenokarsinoma musinosa sebanyak 31 kasus $(11,92 \%)$. Metastasis karsinoma pada kolon dan rektum sebanyak 5 kasus (1,92\%).

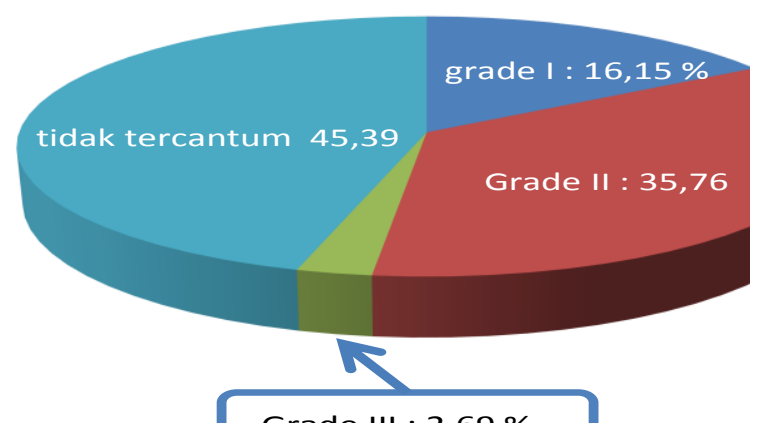

Gambar 2. Distribusi profil carcinoma colorectal menurut grading/diferensiasi

Pada Gambar 2 terlihat bahwa grading/ diferensiasi carcinoma colorectal terbanyak adalah grading II yaitu 93 kasus (35,76\%), dan yang terendah grading III yaitu 7 kasus (2,69\%), dan 75 kasus carcinoma colorectal tidak tercantum grading. 


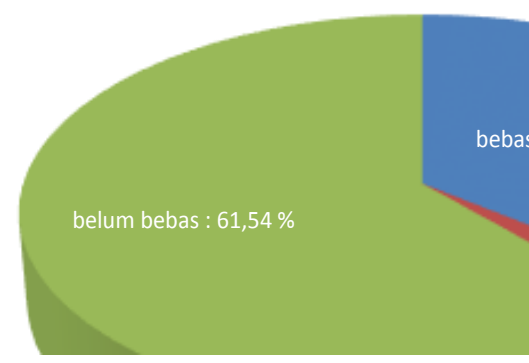

Gambar 3. Distribusi profil carcinoma colorectal menurut keadaan ujung sayatan

Pada Gambar 3 dapat terlihat bahwa dari 260 kasus, 93 kasus (35,77\%) ujung sayatan sudah bebas dari carcinoma colorectal, namun terdapat 7 kasus $(2,69 \%)$ yang belum bebas dan 160 kasus $(61,54 \%)$ tidak tercantum ujung sayatan.

Tabel 3. Distribusi profil carcinoma colorectal menurut gambaran klinis

\begin{tabular}{lcc}
\hline Gambaran Klinis & $\begin{array}{c}\text { Jumlah } \\
\text { kasus }\end{array}$ & $\begin{array}{c}\text { Persentase } \\
\text { (\%) }\end{array}$ \\
\hline BAB berdarah dan & 25 & 9,62 \\
berlendir & 19 & 7,30 \\
lleus obstruksi & 11 & 4,23 \\
Susah BAB & 3 & 1,15 \\
Benjolan di perut & 2 & 0,77 \\
Diare & 1 & 0,39 \\
Nyeri perut bawah & 1 & 0,39 \\
BB turun & 198 & 76,15 \\
Tidak tercantum & 260 & 100 \\
\hline Jumlah & &
\end{tabular}

Tabel 3 memperlihatkan gambaran klinis carcinoma colorectal terbanyak adalah $\mathrm{BAB}$ berdarah dan berlendir sebanyak 25 kasus $(9,62 \%)$ dan ileus obstruksi 19 kasus (7,30\%).

\section{PEMBAHASAN}

Berdasarkan hasil penelitian yang telah dilakukan di laboratorium Patologi Anatomi Fakultas Kedokteran Universitas Andalas selama 3 tahun periode Januari 2009 - Desember 2011 ditemukan penderita carcinoma colorectal sebanyak 260 kasus.

Jumlah kasus pada perempuan lebih tinggi daripada laki-laki, yaitu 141 perempuan (54,23\%) dan 119 laki-laki $(45,77 \%)$ dengan perbandingan laki-laki dan perempuan $1: 1,18$. Hasil ini sesuai dengan kepustakaan yang menyebutkan bahwa kejadian kasus carcinoma colorectal antara laki-laki dan perempuan hampir sama yaitu dengan perbandingan $1: 1^{1,2}$

Kasus carcinoma colorectal mulai meningkat pada kelompok umur 31-40 tahun dan terbanyak ditemukan pada kelompok umur 51-60 tahun. Zuhaira juga mendapatkan hasil yang hampir sama. ${ }^{8}$ Insiden carcinoma colorectal mulai meningkat pada usia 40 tahun, namun dapat muncul di usia lebih muda dengan disertai faktor risiko lain, terutama faktor familial. ${ }^{6}$ Pada penelitian ini terjadi kecenderungan pergeseran umur kearah yang lebih muda, hal ini terbukti dengan ditemukan usia termuda yaitu 16 tahun.

Lokasi carcinoma colorectal terbanyak adalah di rektum yaitu 131 kasus (50,39\%) dan lokasi terendah ditemukan di sekum sebanyak 2 kasus $(0,77 \%)$. Hal ini sesuai dengan kepustakaan yang menyebutkan bahwa sebagian besar kasus carcinoma colorectal muncul di rektum, ${ }^{9}$ sehingga pada saat skreening dengan melakukan rektal toucher masa carcinoma colorectal akan dapat teraba.

BAB berdarah dan berlendir merupakan gejala klinis paling sering timbul dari seluruh gejala klinis yang ditemukan. Hal ini sesuai kepustakaan dan penelitian yang dilakukan oleh Zuhaira bahwa dihubungkan gejala klinis dengan lokasi carcinoma colorectal maka didapatkan hasil yaitu gejala klinis paling banyak muncul di rekum adalah BAB berlendir dan berdarah, hal ini terjadi karena sebagian besar karsinoma yang muncul pada rektum berbentuk ulserasi, sehingga memberikan keluhan berupa BAB berdarah dan berlendir. ${ }^{1,8}$ Sedangkan pada kolon desenden dan sigmoid menimbulkan gejala klinis terbanyak berupa susah BAB dan ileus obstruksi yang terjadi karena sempitnya lumen dan kerasnya konsistensi feses yang melewati daerah ini. ${ }^{10}$ Pada kolon bagian kanan carcinoma colorectal lebih cenderung menimbulkan perdarahan yang tersembunyi dan berulang karena masa carcinoma yang timbul lebih sering berbentuk polipoid dan bunga kubis. Sehingga menimbulkan gejala klinis yang tidak khas, pasien lebih sering mengeluhkan perubahan kebiasaan BAB, badan lemah dan lesu yang disertai 
penurunan berat badan. Pada saat dilakukan pemeriksaan laboratorium akan didapatkan gambaran anemia defisiensi besi yang terjadi karena perdarahan kronik masa tumor pada saluran cerna namun, pada feses tidak tampak keluar darah., ${ }^{1,11}$

Tipe histopatologi terbanyak pada penelitian ditemukan adalah adenokarsinoma sebanyak 217 kasus $(83,47 \%)$ dengan derajat deferensiasi/grading II sebanyak 93 kasus (42,85\%). Hasil yang hampir sama juga diperoleh oleh Zuhaira dan kepustakaan yang menyebutkan gambaran histopatologi carcinoma colorectal paling sering adalah adenokarsinoma, karena sebagian besar lapisan mukosa rektum terdiri atas sel goblet yang berdiferensiasi buruk akibat terpapar lama oleh bahan karsinogen sehingga, sel ini dapat berubah menjadi ganas (adenokarsinoma). ${ }^{2,11,12}$ Karsinoma musinosa ditemukan sebanyak 31 kasus $(11,92 \%)$, hal ini sesuai dengan kepustakaan yang menyebutkan karsinoma musinosa $5-15 \%$ dari seluruh insiden carcinoma colorectal. ${ }^{13}$ Disusul karsinoma sel signet ring 4 kasus $(1,54 \%)$ dan karsinoma tidak berdiferensiasi 2 kasus $(0,77 \%)$ serta ditemukan juga metastasis tumor pada kolon dan rektum sebanyak 5 kasus $(1,92 \%)$.

Pada stadium TNM, data yang diperoleh tidak dapat diolah karena pada data yang diperoleh tidak tercantum dengan jelas ukuran tumor, kelenjar getah bening regional, dan metastasis jauh. Berdasarkan jenis histopatologi dan gejala klinis, jenis histopatologi adenokarsinoma menimbulkan gejala klinis terbanyak berupa BAB berdarah dan berlendir sebanyak 21 kasus, dan 17 kasus lleus obstruksi. Sebagian besar gejala klinis tidak tercantum, sehingga tidak didapatkan data yang akurat.

\section{KESIMPULAN}

Jenis kelamin perempuan lebih banyak dikenai dibandingkan laki-laki. Lokasi paling banyak ditemui carcinoma colorectal adalah rektum dan lokasi terendah ditemukan di sekum. Gejala klinis paling sering mucul adalah BAB berdarah dan berlendir. Gejala klinis ini merupakan yang paling banyak di temukan di rektum

Carcinoma colorectal ditemukan pada usia termuda 16 tahun dan tertua 86 tahun. Carcinoma colorectal mulai meningkat pada kisaran umur 31-40 tahun dan penderita terbanyak pada kelompok umur 51-60 tahun dan terendah pada kelompok umur $<20$ tahun.

Jenis histopatologi terbanyak pada penelitian ini adalah adenokarsinoma dengan derajat deferensiasi / grading terbanyak yaitu deferensiasi / grading II dan terbanyak pada kelompok usia 51-60 tahun. Adenokarsinoma menimbulkan gejala klinis paling banyak berupa $B A B$ berdarah dan berlendir.

\section{DAFTAR PUSTAKA}

1. Zahari A. Deteksi dini, diagnosa dan penatalaksanaan kanker kolon dan rektum. (tesis). Padang: Fakultas Kedokteran Universitas Andalas; 2011.

2. Snell RS. Clinic anatomy for medical student. Edisi ke-6. Jakarta: EGC; 2006.

3. Abdullah M. Tumor kolorektal. Dalam : IImu Penyakit Dalam. Jakarta: FKUI; 2006.

4. Sean PC, Cotterchio M. Cigarette smoking, genetic variants in carcinogen-metabolizing enzymes, and colorectal cancer risk. American Journal of Epidemiology. 2010;172:9-13.

5. Timothy JK, Schatzkin A, et al. Diet, nutrition and the prevention of cancer, Public Health Nutrition; 2004;(1A):137-40.

6. Desen W. Buku ajar onkologi klinis. Edisi ke-2, Jakarta: FKUI; 2008.

7. Eroschenko VP. Di Fiore's atlas of histology with functional correlations. Edisi ke-9. Jakarta: EGC; 2003.

8. Zuhaira S. Gambaran klinis keganasan kolorektal di RSUP Dr. M. Djamil Padang periode Januari 1996 - Desember 2000 (skripsi). Padang: Fakultas Kedokteran Universitas Andalas; 2001.

9. Underwood JCE. General and systemic pathology Edisi ke-2. Sarjadi, penterjemah. Patologi Umum dan Sistemik Edisi ke-2. Jakarta: EGC; 2000.

10. De Jong RS, Yamsuhidayat. Usus halus apendiks, kolon dan anorektum, Dalam: Buku Ajar Ilmu Bedah. Jakarta: EGC; 2005.

11. Robbins, SL. Robbins basic patology .Edisi ke-7. Jakarta: EGC; 2007.

12. Price, SA. Pathophysiology: clinical concepts of 
diseas processes. Edisi ke-6 . Jakarta: EGC; 2005.

13. Gerry del J. Pathology for colon and rectal surgeons. Journal Public Health Nutrition.

2002;7(1A):187-200. 